The 'Parekh Report'

- National identities

without nations and

nationalism

\section{Varun Uberoi}

Department of Politics, History and Brunel School of Law, Brunel University, London, UK
20I5, Vol. I5(4) 509-526

(C) The Author(s) 2015 Reprints and permissions: sagepub.co.uk/journalsPermissions.nav DOI: 10.1 I77/|4687968|5577706

etn.sagepub.com

@SAGE

\begin{abstract}
'Multiculturalists' often advocate national identities. Yet few study the ways in which 'multiculturalists' do so and in this article I will help to fill this gap. I will show that the Commission for Multi-Ethnic Britain's report reflects a previously unnoticed way of thinking about the nature and worth of national identities that the Commission's chair, and prominent political theorist, Bhikhu Parekh, had been developing since the 1970s. This way of thinking will be shown to avoid the questionable ways in which conservative and liberal nationalists discuss the nature and worth of national identities while offering an alternative way to do so. I will thus show that a report that was once criticised for the way it discussed national identities reflects how 'multiculturalists' think about national identities in a distinct and valuable way that has gone unrecognised.
\end{abstract}

\title{
Keywords
}

National identities, multiculturalism, Bhikhu Parekh, Parekh Report, nations, liberal nationalism

\section{Introduction}

Those who show why cultural diversity and intercultural dialogue are valuable, and who advocate policies of multiculturalism like declaring a political community to be multicultural, or teaching children about its multicultural nature, are often referred to as 'multiculturalists' (Modood, 2014: 31; Parekh, 2000a: 6). Such 'multiculturalists' also advocate the importance of national identities (Modood, 2013: 135; Parekh, 2000a: 230), yet many claim that 'multiculturalists' do not do so or that they have an 'anti-national bias' (Barry, 2001: 77; Goodhart, 2013: 201).

\section{Corresponding author:}

Varun Uberoi, Brunel University, Marie Jahoda Building, Cleveland Road, London UB8 3PH, UK.

Email: varun.uberoi@brunel.ac.uk 
Likewise, scholars frequently examine why and how 'multiculturalists' advocate different policies of multiculturalism (Barry, 2001: 315; Crowder, 2013: 50; Jones, 2015: 128). But scholars seldom examine why and how 'multiculturalists' advocate national identities and this article helps to fill this gap by examining how the Commission for Multi-Ethnic Britain (CMEB) did so. I will show that the CMEB's report reflects a previously unnoticed way of thinking about the nature and worth of national identities that its chairman, and prominent political theorist, Bhikhu Parekh, had been devising since the 1970s. This way of thinking is shown to be distinct as it differs to how other prominent thinkers discuss national identities, and valuable as it avoids the questionable ways in which these thinkers discuss the nature and worth of national identities.

Those familiar with the CMEB's Report may think it strange to claim that this report reflects a valuable way to think about national identities because of the way that the media depicted the report. For 'several days' after the report was published, its claims about why cultural minorities should also be seen as 'British' were distorted by journalists who claimed, for example, that the report said 'being British' is racist (Mclaughlin and Neal, 2004; Modood, 2014: 24). Such 'damning headlines' did not prevent some of the report's ideas being used by various politicians (Modood, 2014: 25, 32; Uberoi and Modood, 2013a: 135-36). But scholars who remember these headlines may think that the report is unlikely to reflect a valuable way to think about national identities, yet I will show that it does, as it reflects Parekh's.

Parekh's (1974a, 1978) texts relating to national identities began to appear in the 1970s when membership of the European Economic Community, mass immigration and Scottish and Welsh nationalism led him to ask who 'the British' were any longer. Parekh's texts relating to national identities continued (Parekh, 1986, 1994, 1995a, 2000a, 2009). But his work is not discussed by prominent scholars who debate the value of national identities (Abizadeh, 2002; Mason, 2000, 2012; Miller, 1995, 2000). These scholars may assume that as Parekh devotes limited attention to national identities in well-known books like Rethinking Multiculturalism and $A$ New Politics of Identity, he also devotes limited attention to national identities in general. This assumption is understandable, but it is also mistaken.

This is because Parekh's work on the nature and worth of national identities since the 1970s can be found in his less well-known book chapters, review articles, and published lectures. These pieces are not like peer reviewed journal articles as they contain ideas and arguments that Parekh was 'trying out' and that provoke thought but are, at times, unclear. The relevant texts by Parekh thus require some interpretation to clarify the nature and significance of the ideas and arguments in them or there is a danger that these ideas and arguments will just be ignored or deemed implausible. I will clarify some of Parekh's ideas and arguments using my own terms, examples and ideas just as Parekh (1982: ii) explicitly does with other thinkers and others scholars (Cohen, 1978) do too. I will focus primarily on texts that Parekh wrote prior to the CMEB's report to show that the report reflects how Parekh had long discussed the nature and worth of national 
identities while avoiding the difficulties that other prominent thinkers encounter when they discuss the nature and worth of national identities.

These other prominent thinkers are not Isaiah Berlin (2003), Elie Kedourie (1998) or Ernest Gellner (1983) who all focus on the intellectual, political and functional sources of nationalism and barely mention national identities. Nor are the thinkers I am referring to ones who want to substitute ideas of nations and nationalism with ideas of the 'post-national' or ones who want to explain when, why and how nations and nationalism emerged as such thinkers do not argue specifically for the worth of national identities (Habermas, 1998: 119; Smith, 2001: 43-61). ${ }^{1}$ Instead, the prominent thinkers I am referring to are similar to Parekh as they too discuss at length both what national identities are and why we should value them. These prominent thinkers are those political theorists such as David Miller (1995, 2000) and Yael Tamir (1993) who are often known as 'liberal nationalists' and those such as Roger Scruton (1990, 2006) who are often known as 'conservative nationalists' (Crowder, 2013: 83-91).

Each of these nationalist thinkers has different presuppositions, philosophical approaches, arguments and, thus, political positions. But each of them refers to themselves as a conservative or a liberal and these traditions of thought shape how they think about ideas of nationhood like nations and nationalism. For example, the Burkean idea of polities being a 'partnership' (Burke, 1996: 572) between the living, the dead and the unborn, shapes how a conservative such as Scruton (1990: $305 ; 2014: 82$ ) understands what nations are as he depicts them as those sharing not only descent but a culture bequeathed from one generation to the next. Likewise, the liberal ideal that comes from Immanuel Kant (1929: 335), J. S. Mill (1991: 65) and others of an individual choosing his life 'plan for himself' makes Ernest Renan's (2001: 175, emphasis added) idea of nations constituted by 'consent' and a 'desire to live a common life' attractive to liberals such as Miller (1995: 22-5) and Tamir (1993: 33) who use Renan's ideas. After these thinkers use conservative and liberal traditions of thought to shape their ideas of nationhood they endorse such ideas so much so that Miller (1995: 81), Tamir (1993: 75) and Scruton (2006: 25) argue that nations should be preserved through forms of 'self-rule' or by constituting states. ${ }^{2}$ In doing so, these conservative and liberal thinkers advocate different forms of 'nationalism' (Gellner, 1983:1; Kedourie, 1998: 67; Smith, 2001: 22) and thus unsurprisingly, they are often classified as conservative or liberal nationalists.

As conservative nationalists think nations share descent and a single common culture they unsurprisingly do not claim cultural diversity, intercultural dialogue or policies of multiculturalism are valuable (Scruton, 1990: 305; 2014: 83). But some wellknown liberal nationalists note the value of cultural diversity, elegantly advocate policies of multiculturalism and are seen as 'multiculturalists' too (Kymlicka, 1995: 113; 2001a: 54-58) while other liberal nationalists are not (Miller, 1995: 149, 154). Yet I will show that the CMEB' report avoided the questionable ways in which all such conservative and liberal nationalists discuss national identities yet it reflected Parekh's distinct and valuable way of doing so. And I take two steps to achieve this. 
First, I will show that the way in which the CMEB's report discusses the nature and worth of national identities differs to how conservative and liberal nationalists do. Second, I show how the report's discussion of national identities reflects Parekh's work which also helps to illuminate why these nationalist thinkers discuss the nature and worth of national identities in questionable ways. I conclude by discussing why scholars and British politicians can use the ways in which Parekh and the CMEB advocate national identities.

\section{The CMEB's report}

In the report, people's 'sense of national identity' was said to entail mental images or understandings of what Britain is (CMEB, 2000: 15-16). Such understandings of Britain were disturbed after the second world-war as Britain's imperial, military and economic might disappeared and membership of the European Economic Community, mass immigration and devolution appeared (CMEB, 2000: 22-26). The CMEB said that Britain can respond by trying 'to turn the clock back... digging in, defending... old values....or...it' can try to 'create more ... inclusive' and 'cosmopolitan' images of itself. The report endorses creating such inclusive and cosmopolitan images of Britain as 'one nation'. But this 'nation' is not described as conservative and liberal nationalists might describe a 'nation' (CMEB, 2000: 15, 22, 103).

This more inclusive and cosmopolitan nation is thus not, as conservative nationalists claim, a 'natural' 'organism' whose members share descent and fate and are of the same 'kind' (Scruton, 1990: 314, 317; 2001: 11; 2006: 27). This is neither inclusive nor cosmopolitan and the CMEB were also not discussing a nation as a liberal nationalist might. Liberal nationalists, we saw, follow Renan (2001: 166) and claim members of a nation share a belief that they want to live a 'collective life' and they suggest that 'forgetting' divisive episodes in their history can aid this (Kymlicka, 1995: 189; Miller, 1995: 22-25; Tamir, 1993: 67). Yet for the CMEB, divisive historical episodes about, for example, discrimination or Empire often cannot just be forgotten by minorities and British people must tell 'truths' about these episodes (CMEB, 2000: 103). Likewise, unlike conservative and liberal nationalists, the report, at times, also referred to Britain as a 'state' and a 'post nation' and thus the CMEB seemed, at times, ambiguous and sceptical about Britain being a nation (CMEB, 2000: 15, 36-39; Miller, 1995: 173-174; Scruton, 2006: 16). ${ }^{3}$ And when 'one nation' was defined, the report said it must be 'understood as a community of communities and ... of citizens' (CMEB, 2000: 56). This would ensure British people included in their understandings of Britain not just 'individual' citizens but those who see themselves as part of racial, religious, cultural, regional and other groups (CMEB, 2000: ix). And it is difficult to find conservative and liberal nationalists who make similar claims about what nations are.

The CMEB also claimed that people's national identities had value for two reasons. First, when British people have such understandings of Britain, they have understandings of 'a social unity' or a collective they are part of and this 
helps them to conceive collective challenges, goals and interests with others in this collective called Britain (CMEB, 2000: ix, 16). But such understandings of Britain often exclude racial, cultural and religious minorities and can help to cultivate fear of minorities and discrimination against them too (CMEB, 2000: 16). Yet, if British people had 'mental images' of Britain that include minorities, this would help to normalise minorities in Britain and reduce fear of them and discrimination against them which is then a second reason to value national identities.

Such mental images of Britain are thus not said to be valuable because they are what conservative nationalists call an 'eternal' understanding of the nation - one that is the same for current members as it was for their ancestors and will be for their children (Scruton, 1990: 306). Indeed, the report suggests, as we saw, how such understandings should change. Likewise, the CMEB do not suggest that national identities are valuable because they convey 'life's meaning' (Scruton, 1990: 310). National identities are not said to make sense of life, or reconcile a person to the world in Hegel's famous sense. Likewise, the report does not suggest, as liberal nationalists can, that our national identities aid our ability to make choices (Miller, 2009: 535). But like liberal nationalists, national identities are said in the report to help people to see themselves as a 'community'. Yet this community is not necessarily one of 'solidarity', 'obligation' and 'trust' that people willingly redistribute their income in perhaps because not all communities are like this (Miller, 1995: 83, 91; 2013: 158; Tamir, 1993: 110).

Yet, not all understandings of Britain necessarily include minorities either and the CMEB wanted this to occur, thus the CMEB also discussed 're-imagining' understandings of Britain so that these understandings come, over time, to include minorities. This might occur through at least four means. First, public disputes and controversies such as the 'Rushdie Affair' force people to think about Britain's multicultural nature which is a necessary step if their views of it are to include different cultural minorities (CMEB, 2000: 52). Second, policies of multiculturalism like Britain declaring itself multicultural, as Canada did, or teaching children about Britain's multicultural nature can be used to legitimise and promote understandings of Britain that include different cultural minorities (CMEB, 2000: xviii, 276). Third, perhaps through publicly funded education and the arts, British people must tell 'the truth' about episodes of discrimination and Empire as doing so reveals the implications of seeing British people as solely white and superior to others. Fourth, again using perhaps publicly funded education and the arts, British people must portray how different regional, religious, cultural and other communities exist and often understand Britain differently. Thus, we might say there are 'several' understandings of Britain all of which must come to include minorities (CMEB, 2000: 103).

Where conservative nationalists think national identities cannot be remade as they are natural and can be conserved or can die (Scruton, 1990: 305-306; 2001: 244), clearly the CMEB disagreed as it discussed national identities becoming more inclusive. The latter is something that liberal nationalists discuss too yet only some of them might agree with the CMEB that policies of multiculturalism can aid this 
process (Kymlicka, 2010: 39) while other liberal nationalists who are more sceptical about these policies might disagree (Miller, 1995: 149, 154; 2008: 380). Indeed, where both types of liberal nationalists distinguish between policies of multiculturalism and 'nation-building' policies that promote understandings of a political community through, for example, history classes in schools, the CMEB did not make this distinction (Kymlicka, 2001a: 19, 49; Kymlicka and Banting, 2006: 300; Miller, 2008: 380). ${ }^{4}$ Declaring a political community to be multicultural and teaching children about its multicultural nature promote understandings of a political community too and thus these sorts of policies of multiculturalism may be seen as nation-building policies too. ${ }^{5}$ Likewise, where liberal nationalists follow Renan and advocate 'forgetting' divisive episodes the CMEB advocated 'truth telling'. The report thus exhibits a way of thinking about national identities that differs to how conservative and liberal nationalists think about the same subject, but I will now show that the report reflects Parekh's distinct and valuable way of thinking about national identities.

\section{The report's Parekhian approach to national identities}

Parekh (1974b: 230; 1989: 74-75; 2008: 56) often discusses national identities in two ways. First, he discusses them as the identity of a political community and thus for example, Britain, France, Canada or America's identity and second as an identity that a person might exhibit when they say they feel 'British', 'French', 'Canadian' or 'American'. We often think and talk about national identities in both ways yet conservative and liberal nationalists do not distinguish between them. Nor did the report, but it discussed national identities in both ways.

The report thus discussed understandings of what Britain is and in doing so was referring to a political community's identity. A political community is seen by Parekh as 'a territorially concentrated group of people' who accept 'a common mode of conducting their collective affairs' which often includes a common language, institutions, values, norms, procedures and so on (Parekh, 1994: 501; 1996: 263; 2000a: 181-184). Understandings of what a political community is thus often focus on a territorially concentrated group of people and refer to their history, race, language, their political ideals, values, norms, institutions, the traditions of thought and behaviour that they use to conduct their collective affairs and so on. But understandings of what a political community is can be held by nonmembers, thus De-Tocqueville offered an understanding of America and Rousseau had one when writing about Poland.

Yet, the report said members of a political community have such understandings themselves and publicly funded education can help to provide these understandings. Thus children can be taught in schools about the language, norms, values, ideals, traditions of behaviour, history and so on of their political community. But such understandings of a political community often remain vague and thus politicians, historians, philosophers and other intellectuals often try to clarify them. Such people interpret and relate their political community's ideals, procedures, 
history and so on in different ways according to their own experiences, religious, political and other views. Other members of a political community repeat the different understandings of their political community offered in schools or by politicians or by intellectuals while also interpreting and relating its features in their own different ways too. Thus a political community comes to be understood by its members in a range of different ways hence some in Britain understand it as England, some in Canada think it is multicultural and some in America think it has a 'civil religion'.

However, the report, we saw, also referred to people's senses of national identity and thus them feeling, for example, British, French, American and Canadian and so on. When a person feels this way, they feel their political community shapes what they are and thus they may also say that they are British, French, American and Canadian and so on. And they might feel shaped by their political community because its legal, political and educational institutions regulate their behaviour and condition their notions of what is acceptable and normal. They are partly, yet unavoidably, shaped by their political community. Thus we might say that while political communities are shaped by their members, their members are also shaped by it. Indeed, when someone says they feel British they are not just saying they feel part of Britain as they are also saying that they sense how it shapes them thus they may discuss 'their Britishness' too. Yet such a person is now exhibiting the other way of discussing a national identity that I referred to above where it is not the identity of a political community, but an identity that a person has.

Such an identity does not depict what a person is as a whole, but part of what they are, just as their sexual or religious identities might. Such identities usually only refer to parts of us that help to make us the person we are, like being 'a man', 'a Muslim' or 'an artist'. Thus, it is strange for a person to say they have an identity as a 'reading group member' or a 'commuter' as it is unlikely that these aspects of them make them who they are. But it is not strange for an immigrant to say they have become more British, French, Canadian and American and so on when they sense how their new political community has come to shape them. But such a person must have some, albeit usually vague, understanding of their political community, or they cannot identify it as being something that shapes them. Thus those who say that they feel British, French, Canadian, American and so on must have some, albeit usually vague, understanding of Britain, France, Canada or America and the two ways in which we usually think and talk about national identities are not unrelated. Unsurprisingly, therefore, the CMEB's report said, as we saw, that a person's sense of national identity entails an understanding of what their political community is.

The report also reflected Parekh's scepticism about whether political communities need to be understood as being relatively culturally uniform and thus being what we often call 'nations'. ${ }^{6}$ Few political communities are that culturally uniform and those that were have altered and thus become what Habermas (1998: 119) calls 'post-national'. We saw how the report described Britain as a 'post-nation', but so did Parekh (2001b: 695) who refers to Habermas when saying this. Indeed, the 
report's hesitancy to describe Britain as a nation reflects Parekh's (1995a: 38; 2001b: 695; 2005: 76). He suggested that Britain is a political community that is too culturally diverse to be a nation. But as many in Britain have long been shaped by its legal and political institutions, it is unsurprising that so many also see themselves, in part, as British. This suggests how people in a political community like Britain can have national identities and see themselves 'British', but without being part of a nation called Britain (Parekh, 1995b: 255-256).

Parekh said little about what this means for how we conceive of England, Scotland and Wales, but they might approximate more closely than Britain to how Parekh conceives of nations. A history of separate educational institutions in Scotland, England and Wales, separate legal institutions in Scotland and devolution in Scotland and Wales means that many also see themselves as English, Scottish and Welsh. These are national identities too, thus a person can have more than one national identity and be, for example, British and English. However, those who see themselves as Scottish or Welsh but not British increased just after devolution and since (Ali and Heath, 2013: 6-8; McLean and McMillan, 2005: 4), and this is unsurprising. As legal and political institutions across Britain reduce, so does the extent to which people feel shaped by Britain and so does the extent to which they see themselves as British.

Conservative nationalists are unlikely to challenge Parekh's claim that nations are relatively culturally uniform as they say the same (Scruton, 1990: 315; 2014: 82). But the claims of liberal nationalists suggest that they might think about nations differently. Liberal nationalists might thus question the idea that what we often call nations are relatively culturally uniform by saying instead that nations are people who merely share a territory, history, a willingness to live a collective life and language, norms, beliefs and institutions that are used to govern it (Kymlicka, 2002: 265; Miller, 1995: 22-27; 2000: 27-31). But this seems like a description of a political community in general that could easily refer to the Athenian polis and the Roman civitas (Parekh, 1996: 263), ${ }^{7}$ neither of which are usually thought of as nations. It is unclear why we should refer to the more general category of a political community as a 'nation' if we do not have something more specific in mind. But liberal nationalists might question whether what we call nations are typically culturally uniform in another way. ${ }^{8}$

They might claim that nations need only be culturally uniform at the 'public' level in the sense of a language, norms, values, beliefs and institutions regulating the collective affairs of a citizenry (Kymlicka, 2001a: 55-56; Miller, 1995: 26). Such a 'public culture' originates from a cultural group but leaves space for norms, beliefs, traditions of other cultural groups including minority ones who over time can shape a 'public culture' too (Kymlicka, 1995: 88-89; 2001b: 56-57; Miller, 1995: 25-26; 2008: 388). And describing a nation as relatively culturally uniform hides how 'thin' and thus accommodating a nation's culture can and should be. But while it is difficult to deny that some political communities, like America and Canada, have 'thin' and accommodating public cultures, it remains unclear whether we do, and should, think of these political communities as 'nations', and there is also another problem. 
It is unclear how the cultures that liberal nationalists discuss can be both 'thin' and offer what they call 'meaningful ways of life across the full range of human activities .... encompassing both public and private spheres' (Kymlicka, 1995: 76). For some liberal nationalists, such cultures are 'the defining feature of nations' and as they refer to them as 'pervasive cultures' and 'encompassing cultures' it is unclear why they are also 'thin' (Kymlicka, 1995: 80). It is also unclear why the beliefs, norms and so on of such a 'thin' culture are sufficient to make what liberal nationalists call 'meaningful individual choice(s)' (Kymlicka, 1995: 84). Some choices may be deeply personal and cultures must be 'comprehensive enough to provide the full range of choice' (Miller, 2009: 535; 1995: 26, 42). Likewise, if the cultures that nations do or should have are so accommodating, it is unclear why all prominent liberal nationalists claim that immigration, in large numbers, threatens such cultures (Kymlicka, 2001b: 219; Miller, 2005: 199; Tamir, 1993: 127). Such cultures change anyway, but liberal nationalists claim a nation should be able to 'control' how its culture changes and preference should be given to potential immigrants 'whose cultural values are closer to those of the existing population' (Miller, 2005: 200, 204; 2015: 10; Tamir, 1993: 127). These claims suggest that liberal nationalists are not always thinking about 'thin' and accommodating cultures and often have 'thick' and somewhat unaccommodating cultures in mind. Despite their claims then, liberal nationalists do not always themselves think that a nation's culture can and should be 'thin' and accommodating thus it is unclear why we should think this either.

But liberal nationalists might instead query how Parekh (1995: 255-56) can conceive of national identities without nations. Liberal nationalists may note that something must make an identity 'national' and this is surely a nation which is seemingly why liberal nationalists also often clarify what national identities are by first defining and defending what nations are (Kymlicka, 2002: 265; Miller, 1995: 18; Soutphommasane, 2012: 71). But 'national' need not imply a nation when we refer to 'national negotiations' over a trade treaty or a 'national representative' like a Prime Minister. In such examples, 'national' can merely imply a political community and the same is true with what we usually call 'national identities'. This is why we can disagree about whether America, Canada and Britain are nations, ${ }^{9}$ but this does not deter discussions about America, Canada and Britain's identity or people's American, Canadian and British identities. When referring to national identities, we do not necessarily have nations in mind, but we are often thinking of either the identity of a political community and, for example, America's identity, or the identity of a person when they claim, for example, they are American. Parekh's work illuminates both ways of discussing national identities and shows why specifying the natures of both need not require us to define and defend what nations are.

Yet, Parekh (1974b: 230) also saw how understandings of a political community often focus on the ethnic and cultural characteristics of an ethnic and cultural majority. Ethnic or cultural minorities are thus seen as outsiders even though they are often citizens. This exacerbates the exclusion and discrimination of 
minorities who can also come to feel that they could never be seen as part of such a political community. Thus, at the time of the report's publication, Parekh (2000a: 231) argued that understandings of a political community should not be 'ethnocultural' as the political community easily becomes understood as ethno-culturally uniform, and ethno-cultural minorities are thus excluded from such understandings. But opposing an ethno-culturally uniform understanding of a political community entails opposing a culturally uniform understanding of it as what Parekh calls a nation. Parekh thus seemingly thought such understandings not only need not depict a nation, but also should not do so. ${ }^{10}$

Hence, Parekh (2000a: 231) claimed, at the time of the report, that people's understandings of their political community must be solely 'politico-institutional'. Such understandings could, for example, focus on a constitution and a bill of rights as this occurs in America and does not exclude ethno-cultural minorities. But Tariq Modood (2001: 249), who was otherwise sympathetic to Parekh's ideas, noted that understandings of a political community that are not 'ethno-cultural' and solely 'politico-institutional' cannot include ethno-cultural minorities in them. If the aim is to include ethno-cultural minorities in popular understandings of the political community it is unclear why 'politico-institutional' understandings achieve this aim. Understandably, Parekh stopped claiming that understandings of a political community should be only 'politico-institutional' and discussed how its members are also understood using the other features I referred to earlier (Parekh, 2008: 59; 2009: 36). But note that the report did not claim that Britain should be understood in solely 'politico-institutional' terms perhaps because Modood was the CMEB's academic advisor (CMEB, 2000: 369). ${ }^{11}$

But Parekh (2008: 57) also argued that national identities were valuable for people individually and for their political communities too. Individually, these identities depict, as we saw earlier, part of what makes a person who they are. And a person acknowledging they are, for example, 'American' aids their selfunderstanding. Indeed, even someone who sees himself as a citizen or a worker of the world will overtime usually be shaped by their political community's legal, political and educational institutions and will thus often have something, for example, 'British', 'French', 'American', 'Canadian' and so on about them.

The value of national identities for a political community stems from how its members must, from time to time, conceive collective goals and challenges that they will meet together (Parekh, 2000a: 196). To conduct such activity, it helps if members of a political community think of themselves, inter alia, as a group, but why would they? Members of a political community often differ by race, religion, class, education, occupation and so on, and are mostly unknown to one another, but their national identities can help them to think of themselves as a group. This is because despite their differences and disputes, those who think they are, for example, American, cannot do so without some understanding of America which is usually vague. But if this understanding of America is clear, it helps Americans to visualise the group they think of themselves as. Likewise, those who think of themselves as, for example, 'American' think of themselves as a group just as those 
sharing a religious identity and are 'Muslim', or those sharing a sexual identity and are 'Gay', might. People's national identities are thus valuable as they help members of a political community to think of themselves as a group and recall the CMEB described national identities as being important in a remarkably similar way.

Likewise, many in a political community will sense they are shaped by it as its legal, political and educational institutions seldom focus on just a few of them. Many in a political community will thus say, for example, that they are 'British, 'French', 'American', 'Canadian' and so on, and cannot do so without some, usually vague, understanding of what Britain, France, America and Canada are. Many thus also have understandings of their political community, but Parekh notes how many often also understand it to be solely 'white' and 'Christian' and this helps to generate fear of racial, religious and other minorities, their exclusion and discrimination too. Thus, Parekh (1974b: 230; 1994: 502) noted, again as the CMEB's report later would, that people must alter their understandings of their political communities to include minorities as this could help to remove a source of discrimination and exclusion against minorities.

Parekh had thus long promoted the measures that the report discussed to encourage people's understandings of their political community to include minorities. He thus noted how public controversies like the Rushdie Affair alert people to how their understanding of their political community is exclusive as minorities show why they are citizens and entitled to request changes (Parekh, 1990: 1, 70). Equally, Parekh (1990: 70; 2000a: 229, 235) noted that political communities should declare themselves multicultural as Canada did. Schools should teach children about the political community's multicultural nature as this will help children to develop understandings of it that include minorities. Parekh (1995b: 264) also rejects Renan's advice to forget divisive episodes in the political community's past as these episodes can teach us much about the discrimination and exclusion that follows when popular understandings of a political community suggest it is solely 'white', Christian and so on.

The above reasons for national identities being valuable differ to claiming that people's understandings of their nation are valuable for being an 'eternal' view of it as, we saw, conservative nationalists suggest. It is not only unclear why something that is eternal is also valuable, but Parekh (1994: 504) also notes how understandings of a political community change and thus understandings of Britain are not today what they were even 50 years ago. Parekh (1999: 308) also rejects the conservative nationalist view that national identities have value by conveying 'life's meaning' as it is unclear why, for example, Canada, Britain, France or America's identity or being Canadian, British, French or American would convey this.

But liberal nationalists are right to suggest that choice presupposes something to choose with (Kymlicka, 1989: 166; Miller, 1995: 44). Yet, liberal nationalists, at times, appear to suggest that we choose using our national identities even though they refer to the norms, values, traditions of thought and so on of a 
national culture (Miller, 2009: 535). ${ }^{12}$ It is relatively clear how the language, norms, values and traditions of thought and so on of, for example, an English culture might be used by a person to make choices. But it is less clear how a person's English identity could be used like this. For sure, a person might say that as an Englishman he chooses to fight for England, save it from itself, study English history and so on. But it is unclear whether it is their English culture, English identity, English loyalty or their English education that is being used. Indeed, all of them may be being used simultaneously. It is difficult to say. Likewise, a person might choose not to attend an elite university as he fears he is 'working-class' and will not 'fit-in', or he might choose not to drink alcohol as he is a Muslim. Such choices do not relate in an obvious way to national identities but to other identities instead, and perhaps with such points in mind, Parekh (2000a: 103) does not connect national identities and choice.

Further, for Parekh (1999: 313-314) national identities need not cultivate the 'solidarity', 'obligation' and 'trust' that people require to redistribute their income as liberal nationalists hope (Kymlicka, 1995: 77; Miller, 1995: 83, 91,92; 2013: 90; Tamir, 1993: 110). This is because, whether national identities aid such redistribution is an empirical issue and liberal nationalists accept this thus they subtly show how national identities must be conceived to examine this empirical issue (Miller and Ali, 2014). But liberal nationalists do not show what 'solidarity', 'trust' and 'obligation' are or what forms of them are needed or what our indicators for them are or how we can disaggregate national identities as stimulating them from other stimuli. Indeed, while empirical evidence does not disprove what liberal nationalists claim it does not support it either as liberal nationalists admit (Miller and Ali, 2014: 240, 254, 257). Parekh $(1999 ; 2012)$ has thus long criticised this way of arguing that national identities are valuable and does not include it among his own ways of describing their value.

These arguments from conservative and liberal nationalists are questionable and Parekh argues for the value of national identities in ways that seem less so. But Parekh is not a nationalist in the sense that I referred to earlier. Parekh does not discuss the importance of nations or the importance of nations having 'self-rule' or constituting states as, for example, Scottish and Welsh nationalists might. Parekh thus does not advocate the nationalism (Kedourie, 1998: 67; Smith, 2002: 9; Gellner, 1983: 1) that we often think is necessary to call someone a nationalist. But Parekh was also not unconcerned with the goals of those seeking secession, independence or greater 'autonomy' in a more federal political structure. He thought that such groups or communities need not always be nations, that in some cases arguments can be offered not to secede and that nationalism was not the only way to think about their goals. But Parekh (1990: 191; 2011: 33-35) showed why rectifying previous injustice, preventing further abuse, the need for 'recognition' and better representation could all be used in different ways to plausibly justify the goals of such groups and why counterarguments were often implausible too. In this way, Parekh and the CMEB's report outline or sketch for us how we can begin to think about the importance of national identities without nations, nationalism and without being nationalists. 


\section{Conclusion}

This article has shown that the CMEB's report reflected Parekh's distinct and valuable way of thinking about national identities which has previously gone unnoticed. Parekh thus does not assume that explaining what national identities are requires us to explain what nations are, but it involves discussing at least two ways in which we often think about national identities, as for example, America's identity, and being American. Parekh also shows why national identities are valuable but not, as we saw above, by claiming they convey an 'eternal' understanding of the political community, life's meaning, can aid choice or the redistribution of income. Such arguments are questionable and thus Parekh avoids them. The report we have seen avoids these arguments too and was thus repeatedly criticised by journalists for its discussion of national identities even though it reflects a way to think about national identities that avoids the questionable arguments of rival ways to think about them. Both within and beyond the academy, Parekh as a prominent 'multiculturalist' used his academic and non-academic writing to articulate a distinct and valuable way to discuss the nature and worth of national identities that we saw in the introduction others often ignore.

But much can be gained from studying the ways in which a 'multiculturalist' like Parekh thinks about the nature and worth of national identities. For example, liberal nationalists depict what national identities are and why they have value, as does Parekh, but he avoids some of their more questionable arguments. Liberal nationalists may thus benefit from expanding upon Parekh's work to address the relationships between national identities, citizenship, what rights immigrants who are not yet citizens are entitled to and so on (Miller, 2005; 2007). Parekh and other 'multiculturalists' say surprisingly little about these issues. But as national identities are central to what liberal nationalists say about them, clearer notions of what national identities are and why they are important are needed, and Parekh may help to provide them.

Parekh's work may also be important for those who seek to escape the need for national identities by arguing that citizens only need to 'possess a sense belonging to a polity' in the sense that they 'identify with it' and see it as theirs (Mason, 2000: 127; 2012: 181). This is because a citizen sensing he belongs to a polity, and for example, belongs to America, presupposes he has at least some, albeit usually vague, understanding of America which is one way in which Parekh describes national identities. And if citizens should 'identify' with their polity and see it as theirs, this might occur if they think their polity helps to shape what they are, and makes them, for example, British, French, Canadian, American and so on which is the second way in which Parekh describes national identities. Neither of the ways in which we usually think and talk about national identities seems easy to escape. Similarly, those who criticise liberal nationalists and who endorse 'post-national' or 'post-nationalist' political communities may benefit from Parekh's work (Azibedeh, 2002: 495; Müller, 2007: 63). This is because, like them, Parekh accepts that political communities are often no longer nations and he does not advocate 
nationalism or being a nationalist. But Parekh does not take the step of rejecting national identities as he recognises why what we usually call national identities need not be as connected to nations and nationalism as some think.

Likewise, British politicians can make use of the report and Parekh's way of thinking about the nature and worth of national identities. This is because few senior British politicians today would echo John Major (1993) and talk about Britain remaining 'unamendable in all of its essentials'. And many senior British politicians already discuss promoting more inclusive understandings of Britain as Tariq Modood and I show elsewhere (Modood, 2014: 31; Uberoi and Modood, 2013a, 2013b). Liberal nationalist reasons can be used to justify this as some public intellectuals suggest, and this may accord with the 'muscular forms of liberalism' that some British politicians discuss too (Goodhart, 2013: 285). But if British politicians use liberal nationalists reasons to justify promoting more inclusive understandings of Britain, it is unclear how they avoid the questionable arguments that we saw liberal nationalists can make. The CMEB report and 'multiculturalists' like Parekh thus offer British politicians another way to justify the importance of understandings of Britain being more inclusive. There is then some scholarly and non-scholarly value in the way that 'multiculturalists' advocate national identities and more research into the many different ways in which different 'multiculturalists' (Modood, 2013; Uberoi, 2007) do so is needed.

\section{Acknowledgements}

I am grateful to Marco Antonsich, Geoff Levey, Andrew Mason, Bhikhu Parekh and Tatiana Matejskova for their feedback. Tariq Modood deserves special thanks for his comments on this article and discussions we have had over many years now about the CMEB report and Parekh's political thought. Elise Rietveld also gave detailed feedback on of this article and helped me to improve it greatly. I am also grateful to John Bowen, Per Mouritsen and Nils Holtug for inviting me to the Universities of Washington, Aarhus and Copenhagen as I presented very early versions of this piece at these universities.

\section{Notes}

1. Likewise, Benhabib (2008), Nussbaum (1996) and Viroli (1995) only briefly mention national identities and discuss instead replacing ideas of nations and nationalism with ideas of 'republican patriotism' or 'cosmopolitanism'.

2. Scruton (1990) rejects nationalism but later Scruton (2006: 16, 21, 25) accepts the importance of nation-states and endorses the importance of nations having states and is thus a nationalist in the sense described.

3. By saying the report seemed at times sceptical about Britain being a nation I am, I hope, echoing Modood's (2014: 28) claim that the report was unclear at times about Britain being a nation.

4. Kymlicka and Banting (2006: 301) come close to not distinguishing between nationbuilding policies and policies of multiculturalism when they note how the latter can help to foster national solidarity yet they retain the distinction between the two types of policies. Likewise, they note how in Canada policies of multiculturalism have been 
used to foster national pride in multiculturalism which I agree with (Uberoi, 2007, 2008, 2009) but again this differs to claiming policies of multiculturalism can be nationbuilding policies.

5. The fact that liberal nationalists conceive of nation-building policies as promoting understandings of a political community can be seen by considering how, for example, celebrating symbols, heroes and so on are listed as potential nation-building policies (Kymlicka, 2001: 34; Kymlicka and Banting, 2006: 300).

6. Elsewhere, I suggest that Parekh thinks nations are morally, ethnically and culturally uniform but this presupposes that ethnicity and morality are unrelated to culture, and as Parekh does not take this position I describe his understanding of a nation differently here.

7. These are examples that Parekh used to describe a polity but I use these examples in a different way to him.

8. Yack (2012: 70) and others accept that nations have existed since antiquity, but it remains unclear why liberal nationalists refer to the more general category of a political community as a nation if all they have in mind is a political community.

9. See Bechhoffer and McCrone (2007: 253), Uberoi and McLean (2009: 41) and Miller (1995: 141).

10. Indeed, if a nation is defined as a homogenous ethno-cultural group, Parekh's entire philosophical system is about rejecting this. See Uberoi (2015).

11. Modood (2014: 24) 'took an active part in the collective authorship' of the CMEB report.

12. I cannot find this conflation between identity and culture in Miller's other work. But as Miller (2009: 535) is speaking on behalf of all liberal nationalists and he is such an important liberal nationalist himself, I did not think I could ignore this conflation. This is especially as other liberal nationalists slip from discussing culture to identity when setting up their discussion of why cultures aid choice. See Kymlicka (1995: 77).

\section{References}

Abizadeh A (2002) Does liberal democracy presuppose a cultural nation? Four arguments. American Political Science Review 96(3): 495-509.

Ali S and Heath A (2103) Future Identities: Changing Identities in the UK-The Next Years. London: Government Office for Science.

Barry B (2001) Culture \& Equality. Cambridge: Polity.

Bechhoffer F and McCrone D (2007) Being British: a crises over identity. The Political Quarterly 78(2): 251-260.

Benhabib S (2008) Another Cosmopolitanism. Oxford: Oxford University Press.

Berlin I (2003) The bent twig: on the rise of nationalism. In: Berlin I (ed.) The Crooked Timber of Humanity. London: Pimlico, pp.238-263.

Burke E (1996) 'Reflection on the Revolutions in France'. Modern Political Thought, Readings From Machiavelli to Nietzche. Oxford: Hackett.

Cohen GA (1978) Karl Marx's Theory of History: A Defence. Oxford: Oxford University Press.

Commission on the Future of Multi-Ethnic Britain (CMEB) (2000) The Parekh report. London: Profile Books.

Crowder G (2013) Theories of Multiculturalism. Cambridge: Polity.

Gellner E (1983) Nations and Nationalism. Oxford: Blackwell. 
Goodhart D (2013) The British Dream: Successes and Failures of Post-war Immigration. London: Atlantic Books.

Habermas J (1998) The Inclusion of the Other. Cambridge, MA: MIT Press.

Jones P (2015) 'Liberal Equality and Accommodation'. In: Uberoi V, Modood T (eds)

Multiculturalism Rethought. Edinburgh: Edinburgh University Press, pp.126-157.

Kant I (1929) Selections. London: Charles Schreiber and Sons.

Kedourie E (1998) Nationalism. Blackwell: Oxford.

Kymlicka W (1989) Liberalism, Community and Culture. Oxford: Clarendon Press.

Kymlicka W (1995) Multicultural Citizenship. Oxford: Clarendon Press.

Kymlicka W (2001a) Can Liberal Pluralism Be Exported? Oxford: Oxford University Press.

Kymlicka W (2001b) Politics in the Vernacular. Oxford: Oxford University Press.

Kymlicka W (2002) Contemporary Political Philosophy. Oxford: Oxford University Press.

Kymlicka W (2010) The Rise and Fall of Multiculturalism?: New debates on inclusion and accommodation in diverse societies. In: Vertovec S, Wessendorf S (eds) Multiculturalism Backlash. London: Routledge, pp.32-50.

Kymlicka W and Banting B (2006) Immigration multiculturalism and the welfare state. Ethics and International Affairs 20(3): 281-304.

Major J (1993) Speech to the conservative group for Europe. Available at: http://www.johnmajor.co.uk/page1086.html, last accessed 10 May 2014.

Mason A (2000) Community Solidarity Belonging. Cambridge: Cambridge University Press.

Mason A (2012) Living Together as Equals: the demands of citizenship. Oxford: Oxford University Press.

McLaughlin E and Neal S (2004) Misrepresenting the multicultural nation. Policy Studies 25(3): 155-174.

McLean I and McMillan A (2005) State of the Union. Oxford: Oxford University Press.

Mill JS (1991) On Liberty and Other Essays. Oxford: Oxford University Press.

Miller D (1995) On Nationality. Oxford: Clarendon Press.

Miller D (2000) Citizenship and national identity. Cambridge: Polity Press.

Miller D (2005) Immigration: the case for limits. In: Cohen A, Wellman H (eds)

Contemporary debates in applied ethics. Oxford: Blackwell, pp.193-206.

Miller D (2007) National Responsibility. Oxford: Oxford University Press.

Miller D (2008) Immigrants, nations and citizenship. The Journal of Political Philosophy 16(4): 371-390.

Miller D (2009) Nationalism. In: Drysek J, Honig B, Phillips A (eds) The Oxford Handbook of Political Theory. Oxford: Oxford University Press, pp. 529-545.

Miller D (2013) Justice for Earthlings. Cambridge, MA: Cambridge University Press.

Miller D (2015) Justice and Immigration. European Journal of Political Theory (1): 1-19.

Miller D and Ali S (2014) Testing the national identity argument. European Political Science Review 6(2): 237-259.

Modood T (2001) Their liberalism our multiculturalism. British Journal of Politics and International Relations 3(2): 245-257.

Modood T (2013) Multiculturalism. Cambridge: Polity Press.

Modood T (2014) Multiculturalism and Britishness: provocations, hostilities and advances. In: Garbaye R, Schnapper P (eds) The Politics of Ethnic Diversity in the British Isles. Basingstoke: Palgrave Macmillan, pp.21-37.

Müeller JW (2007) Constitutional Patriotism. Princeton: Princeton University Press. 
Nussbaum M (1996) Patriotism and cosmopolitanism. In: Nussbaum M (ed) For Love of Country. Boston: Beacon Press.

Parekh B (1974a) The spectre of self-consciousness. In: Parekh B (ed.) Colour, Culture and Consciousness: Immigrant Intellectuals in Britain. London: George Allen \& Unwin Ltd, pp.41-85.

Parekh B (1974b) Postscript. In: Parekh B (ed.) Colour, Culture and Consciousness: Immigrant Intellectuals in Britain. London: George Allen \& Unwin Ltd, pp.220-246.

Parekh B (1978) Asians in Britain: problem of opportunity? In: Commission for Racial Equality (ed.) Five Views of Multi-racial Britain. London: Commission for Racial Equality, pp.36-55.

Parekh B (1982) Marx's Theory of Ideology. London: Croom Helm.

Parekh B (1986) The 'New Right' and the politics of nationhood. In: Deakin N (ed.) The New Right: Image and Reality. London: The Runnymede Trust.

Parekh B (1989) Ghandi's Political Philosophy: A Critical Examination. Basingstoke: Macmillan.

Parekh B (1990) Britain and the social logic of pluralism. In: Commission for Racial Equality (ed.) Britain: a Plural Society. Report of a Seminar. London: Commission for Racial Equality, pp.58-76.

Parekh B (1994) Discourses on National Identity. Political Studies XLII: 492-504.

Parekh B (1995a) Ethnocentricity of the nationalist discourse. Nations and Nationalism 1(1): 25-52.

Parekh B (1995b) The concept of national identity. New Community 21(2): 244-268.

Parekh B (1996) Citizenship and political obligation. In: King P (ed.) Socialism and the Common Good. London: Frank Cass, pp.259-289.

Parekh B (1999) The incoherence of nationalism. In: Beiner R (ed.) Theorizing Nationalism. New York: State University of New York Press, pp.295-327.

Parekh B (2000a) Rethinking Multiculturalism. Basingstoke: Macmillan.

Parekh B (2000b) Defining British identity. Political Quarterly 71(1): 1-13.

Parekh B (2001a) Integrating Minorities. London: Institute of Contemporary Arts.

Parekh B (2001b) The future of multi-ethnic Britain: reporting on a report. The Round Table: the Commonwealth Journal of International Affairs 90(362): 691-700.

Parekh B (2005) Response To David Goodhart. In: Goodhart D, Progressive Nationalism. Demos, pp. 73-76.

Parekh B (2008) A New Politics of Identity: Political Principles for an Interdependent World. Basingstoke: Palgrave Macmillan.

Parekh B (2009) 'Being British'. In: Gamble A, Wright T (eds) Britishness Perspectives on The British Question. Oxford: Wiley, pp.32-41.

Parekh B (2011) Liberal democracy and national minorities. In: Requejo F, Caminal M (eds) Political Liberalism and Plurinational Democracies. London: Routledge, pp.31-43.

Parekh B (2012) Multicultural society and the welfare state. In: Connelly J, Hayward J (eds) The Withering of the Welfare State. Basingstoke: Palgrave Macmillan, pp.52-68.

Renan E (2001) What is a nation? In: Pecora V (ed.) Nations and Identities: Classic Readings. Oxford: Blackwell, pp.162-176.

Scruton R (1990) In defence of the nation. In: Clark J (ed.) Ideas and Politics in Modern Britain. London: Macmillan, pp.299-328.

Scruton R (2001) England: An Elegy. London: Continuum. 
Scruton R (2006) Arguments for Conservatism: A Political Philosophy. London: Continuum.

Scruton R (2014) How to be a Conservative. London: Bloomsbury Publishing.

Smith A (2001) Nationalism. Cambridge: Polity Press.

Soutphommasane T (2012) The Virtuous Citizens. Cambridge: Cambridge University Press. Tamir Y (1993) Liberal Nationalism. Princeton: Princeton University Press.

Uberoi V (2007) Social unity in Britain. Journal of Ethnic and Migration Studies 33(1): $141-157$.

Uberoi V (2008) Do policies of multiculturalism undermine national identities? Political Quarterly 79(3): 404-417.

Uberoi V (2009) Multiculturalism and the Canadian charter of rights and freedoms. Political Studies 57(4): 805-827.

Uberoi V (2015) Introduction. In: Uberoi V, Modood T (eds) Multiculturalism Rethought. Edinburgh University Press.

Uberoi V and McLean I (2009) Britishness - the role of the state. Political Quarterly 79(s1): 41.

Uberoi V and Modood T (2013a) Has multiculturalism in Britain retreated? Soundings 53: $129-142$.

Uberoi V and Modood T (2013b) Inclusive Britishness: a multiculturalist advance. Political Studies 61(1): 23-41.

Viroli M (1995) For Love of Country. Oxford: Oxford University Press.

Yack B (2012) Nationalism and the Moral Psychology of Community. Chicago: Chicago University Press. 